\title{
Antibacterial Property and Biocompatibility of Silver, Copper, and Zinc in Titanium Dioxide Layers Incorporated by One-Step Micro-Arc Oxidation: A Review
}

\author{
Masaya Shimabukuro \\ Department of Biomaterials, Faculty of Dental Science, Kyushu University, 3-1-1 Maidashi, Higashi-ku, \\ Fukuoka 812-8582, Japan; shimabukuro@dent.kyushu-u.ac.jp; Tel.: +81-92-642-6346
}

Received: 3 October 2020; Accepted: 19 October 2020; Published: 20 October 2020

\begin{abstract}
Titanium (Ti) and its alloys are commonly used in medical devices. However, biomaterial-associated infections such as peri-implantitis and prosthetic joint infections are devastating and threatening complications for patients, dentists, and orthopedists and are easily developed on titanium surfaces. Therefore, this review focuses on the formation of biofilms on implant surfaces, which is the main cause of infections, and one-step micro-arc oxidation (MAO) as a coating technology that can be expected to prevent infections due to the implant. Many researchers have provided sufficient data to prove the efficacy of MAO for preventing the initial stages of biofilm formation on implant surfaces. Silver $(\mathrm{Ag})$, copper $(\mathrm{Cu})$, and zinc $(\mathrm{Zn})$ are well used and are incorporated into the Ti surface by MAO. In this review, the antibacterial properties, cytotoxicity, and durability of these elements on the Ti surface incorporated by one-step MAO will be summarized. This review is aimed at enhancing the importance of the quantitative control of $\mathrm{Ag}, \mathrm{Cu}$, and $\mathrm{Zn}$ for their use in implant surfaces and the significance of the biodegradation behavior of these elements for the development of antibacterial properties.
\end{abstract}

Keywords: titanium; biofilm; infection; micro-arc oxidation; silver; copper; zinc; antibacterial properties; coating; implant

\section{Current Clinical Issues Related to Titanium (Ti)}

Titanium (Ti) and its alloys are used for devices requiring strength, elongation, and long-term bone bonding in orthopedics, cardiovascular medicine, dentistry, and other applications owing to their high corrosion resistance, specific strength, and tissue compatibility [1]. Compared with other metals, $\mathrm{Ti}$ has the unique property of osseointegration. Osseointegration is defined as "the formation of a direct interface between an implant and bone, without intervening soft tissue. No scar tissue, cartilage, or ligament fibers are present between the bone and implant surface. The direct contact of bone with implant surface can be verified microscopically" [2]. The hard-tissue compatibility of Ti is caused by osseointegration. In other words, the reaction that occurs at the interface between $\mathrm{Ti}$ and bone tissue promotes bone formation and bone binding. These are the well-known advantages of using Ti in implant materials compared with other metals. The interface between Ti and bone tissue is apparent soon after implantation at the micrometer and nanometer scales [3-8]. The Ti surface is covered by an amorphous titanium oxide $\left(\mathrm{TiO}_{2}\right)$ layer and shows a high corrosion resistance in vivo [9-13] along with a low toxicity. Therefore, the Ti surface is crucial as a beneficial interface between Ti and the bone tissue.

However, even with a high hard-tissue compatibility, several clinical issues have been reported for Ti and are summarized in Table 1. The disadvantages of metals for their use as biomaterials include their 
artificial nature and lack of bio-functional properties. The exploration of novel and advanced strategies to prevent these clinical issues is an active area of research. Among these, biomaterial-associated infections on Ti implants have been recognized as devastating and threatening complications for patients and orthopedists, and many researchers have focused on this issue. This review focusses on one-step micro-arc oxidation (MAO), which is one of the coating techniques that is expected to prevent biomaterial-associated infections.

Table 1. Current clinical issues related to Ti use in the body.

\begin{tabular}{cc}
\hline Problem & Medical Devices \\
\hline Stress shielding & Bone plate; stem of artificial joint \\
Adhesion to bone & Bone screw; bone nail \\
Cracking and fracture by excessive deformation & Spinal rod; maxillofacial plate \\
Crevice corrosion; pitting & Stent graft \\
Fracture & Endodontic file \\
Corrosion with fluoride & Dental restorative \\
Cytotoxicity & All devices \\
Biomaterial-associated infections; peri-implantitis; & Abutment of dental implant; orthodontic implant \\
prosthetic joint infection & anchor; percutaneous device; screw of external bone \\
& fixator; artificial joint \\
\hline
\end{tabular}

\section{Biomaterial-Associated Infections}

Biomaterials are used in implants and devices in medical applications that are used in diagnosis and temporary support or the permanent restoration of human function. These applications have always been hindered by the development of biomaterial-associated infections linked to implant/device use [14-18]. The current incidence rates of infections in various implant/device applications are well summarized in [19]. Infections can occur on all biomaterial surfaces. The onset of biomaterial-associated infections is frequently accompanied by patient morbidity and discomfort, and can lead to the surgical replacement of the implant after lengthy and unsuccessful attempts to mitigate infections using antibiotics. This clinical routine incurs additional health care costs and patient morbidities. Revision surgery to replace a total hip arthroplasty triples the cost of the primary implant procedure and amounts to an average of US $\$ 75,000[20,21]$.

It is essential to prevent the formation of biofilms, which are the main cause of biomaterial-associated infections. Biofilms are hallmarks of extracellular polymeric matrix production [22]. Many bacteria that form biofilms produce a variety of extracellular polymeric substances (EPSs). The establishment of a biofilm is the final state of bacterial infections that can persist despite treatment. Biofilms are more resistant to a variety of antimicrobial agents, including antibiotics, owing to the three-dimensional structure of the biofilm and the physiology of the adherent bacteria [23-27]. The mechanism of biofilm formation on biomaterial surfaces is shown in Figure 1.

Biofilms are generally formed as a result of bacterial adhesion, growth, colony formation, EPS production, quorum sensing (QS) signals, and the formation of nutrition channels. Bacterial invasion can occur due to implant surgery or the hematogenous spread of bacteria. The invading bacteria initially adhere to the biomaterial surface through cell surface-associated adhesions $[27,28]$. The attached bacteria can proliferate and form colonies. During this time, an EPS matrix is generated. The chemical and physical composition of the EPS matrix varies between species and growth conditions [27]. Regardless of these differences, the outcome of EPS production typically is the enhanced adhesion of the bacteria embedded in the matrix. In addition, the interaction between bacteria and eukaryotic cells is promoted-for example, the matrix components produced by some bacteria are required for the adhesion of bacteria to a variety of protein components of the host cells at the onset of infection [29,30]. In addition, the EPS matrix protects bacteria from antibiotics, antimicrobial agents, and host innate immune components [23,31-33]. Thus, the EPS matrix is a multi-functional and protective scaffold that forms specific chemical and physical microenvironments. 
Within the biofilm, bacteria develop a quorum-sensing system for communication. Quorum sensing is the regulated gene expression that occurs in response to fluctuations in cell density [34]. The quorum sensing process controls and optimizes a variety of activities and leads to bacterial diversity in biofilms. The result is often the recalcitrance of implant-related biofilm infections to antibiotic treatments. Mature biofilms can release aggregates of EPSs that can spread the infection. Often, the only way to eradicate the infection and prevent sepsis is to remove the contaminated device from the patient. To avoidthis, biofilm formation must be prevented by inhibiting the initial stage of biofilm formation during the device implantation. Therefore, the implant materials require antibacterial properties to inhibit this stage.

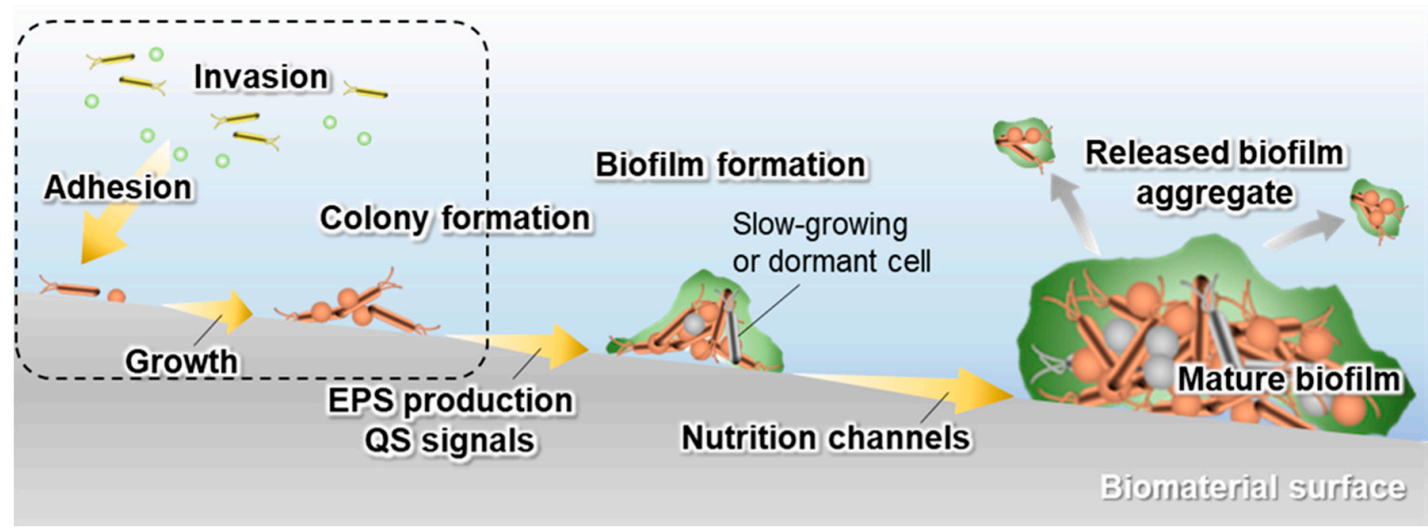

Figure 1. Schematic diagram of the biofilm formation process. The dashed area represents the initial stages of biofilm formation.

\section{Strategies to Prevent Biofilm Formation by Coatings}

Novel and effective strategies for the prevention of biofilm formation on biomaterials have become an active area of research. Surface functionalization based on surface coating technology aims to inhibit the initial stages of biofilm formation-namely, bacterial invasion, adhesion, and growth; in particular, anti-biofouling (or anti-adhesive) properties and antibacterial properties are key bio-functional properties. Anti-biofouling, which relies on the chemical and physical properties of polymers, can control biofilm formation in the absence of antibacterial agents [35-40].

The antibacterial strategy has become a very active area of research for the prevention of biofilm formation. Antibacterial agents can be incorporated on the device surface. Bacteria that encounter the surface can be killed, nullifying their adhesion and growth. Antibiotics, peptides, enzymes, organic cation compounds, non-organic compounds, and elements have been used as antibacterial agents. Among them, silver $(\mathrm{Ag})$, copper $(\mathrm{Cu})$, and zinc $(\mathrm{Zn})$ have been extensively used as major antibacterial elements because of their excellent antibacterial effects. Since the antibacterial properties and host cell toxicities of these elements are dose-dependent, it is important to control the concentration of antibacterial elements to kill the bacteria on implant surfaces with minimal or no harmful effects on the living host tissue [41-53]. Therefore, coating technologies play an important role in the fabrication of antibacterial surfaces because they can easily affect the surface composition of implants.

\section{Micro-Arc Oxidation (Mao)}

MAO, which is also termed anodic spark deposition (ASD) or plasma electrolytic oxidation (PEO), is an electrochemical treatment for valve metals. MAO is a wet process that is performed at high voltages using a specific electrolyte. A hard and thick porous oxide layer forms on the metallic substrate, and MAO allows the elements comprising the electrolyte to be incorporated into the oxide layer. This layer has a high adhesive strength compared to various coating layers because the oxide layer grows in the direction of the substrate. Many studies have reported the advantages of MAO for 
Ti-based materials for medical devices. MAO improves the hard-tissue compatibility of Ti when the electrolyte contains calcium (Ca) and phosphate (P). The biocompatibility of MAO coatings has been demonstrated by numerous in vitro and in vivo tests [54-67]. On the other hand, since $2009 \mathrm{MAO}$ has been used to incorporate antibacterial elements onto the Ti surface to generate an antibacterial surface. A schematic diagram of the incorporation of $\mathrm{Ag}, \mathrm{Cu}$, and $\mathrm{Zn}$ by $\mathrm{MAO}$ and their surface characterization results are shown in Figure 2. MAO easily and selectively incorporates the required elements into the titanium surface owing to the compositional control in the electrolyte. Table 2 summarizes the published articles related to the one-step MAO-based incorporation of antibacterial elements onto the Ti surface [68-102]. It should be noted that some researchers have combined MAO and other surface modification processes [103-106]. Many researchers have used one-step MAO to incorporate antibacterial elements onto Ti surfaces and have provided sufficient data to prove the efficacy of this approach. The MAO treatment of Ti using electrolytes containing antibacterial elements has proven effective against various bacteria, including Escherichia coli (E. coli), Staphylococcus aureus (S. aureus), methicillin-resistant Staphylococcus aureus (MRSA), Actinobacillus actinomycetemcomitans (A. actinomycetemcomitans), Streptococcus mutans (S. mutans), and Pseudomonas aeruginosa (P. aeruginosa). In addition, the structure of the titanium dioxide layer formed by MAO captures the bacteria and leads to the trap-killing system on the implant surface [106]. Therefore, the typical porous structure formed by $\mathrm{MAO}$ is beneficial for the development of antibacterial properties.

(a)

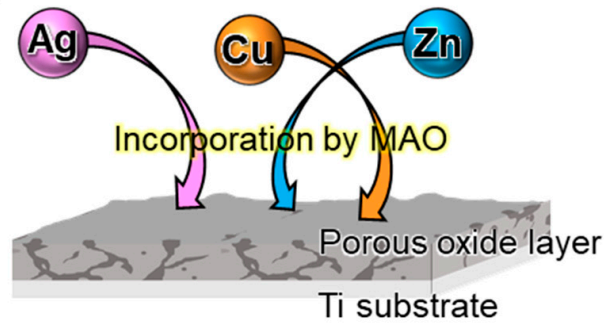

(c)

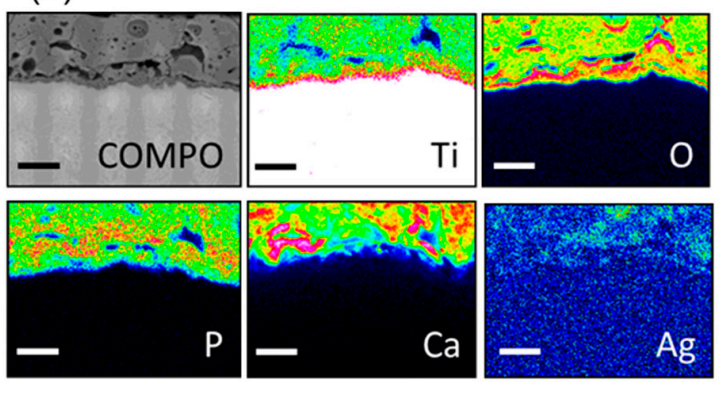

(b)
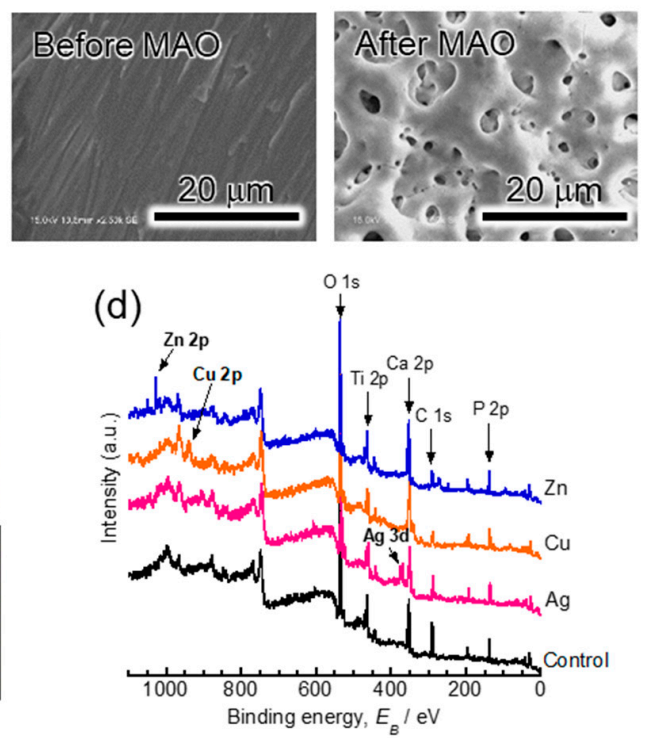

Figure 2. (a) Schematic diagram of the formation of a porous oxide layer on the Ti substrate and the incorporation of antibacterial elements by micro-arc oxidation (MAO). (b) Scanning electron microscopy (SEM) images of the Ti surface before and after MAO; (c) cross-sectional views of Ag-incorporated porous oxide layer and element mapping results by electron probe micro analyzer (EPMA). Scale bar represents $10 \mu \mathrm{m}$; (d) X-ray photoelectron spectroscopy (XPS) survey scan spectra obtained from the specimen, with and without antibacterial elements. The spectra obtained from the control (specimen without antibacterial elements), Ag-, $\mathrm{Cu}$-, and $\mathrm{Zn}$-incorporated specimens are shown from the bottom to the top. Specimens were MAO-treated at $400 \mathrm{~V}$ using the electrolytes containing $150 \mathrm{mM}$ of calcium acetate and $100 \mathrm{mM}$ of calcium glycerophosphate with or without $2.5 \mathrm{mM}$ of silver nitrate, $2.5 \mathrm{mM}$ of copper chloride, or $2.5 \mathrm{mM}$ of zinc chloride. 
Table 2. Summary of the published articles related to the incorporation of antibacterial elements onto the Ti surface by one-step MAO.

\begin{tabular}{|c|c|c|c|c|}
\hline Year & Authors & Elements & Tested Bacteria & Tested Cells \\
\hline 2009 & Song et al. [68] & $\mathrm{Ag}$ and $\mathrm{Pt}$ & S. aureus and E. coli & HOS and MG63 \\
\hline \multirow[t]{3}{*}{2013} & Lin et al. [69] & $\mathrm{Bi}$ & $\begin{array}{l}\text { S. aureus, MRSA, and } \\
\text { A. actinomycetemcomitans }\end{array}$ & MG63 \\
\hline & Zhu et al. [70] & $\mathrm{Cu}$ & S. aureus & MG63 \\
\hline & Zhao et al. [71] & $\mathrm{Zn}$ & S. mutans & MG63 \\
\hline \multirow[t]{3}{*}{2014} & Zhao et al. [72] & $\mathrm{Zn}$ & - & - \\
\hline & Yu et al. [73] & $\mathrm{Mn}$ & S. aureus and E. coli & rBMMSC \\
\hline & Yao et al. [74] & $\mathrm{Cu}$ & S. aureus and E. coli & - \\
\hline 2015 & Teker et al. [75] & $\mathrm{Ag}$ & S. aureus and E. coli & - \\
\hline \multirow[t]{4}{*}{2016} & Rokosz et al. [76] & $\mathrm{Cu}$ & - & - \\
\hline & Zhang et al. [77] & $\mathrm{Cu}$ & S. aureus & L-929 \\
\hline & He et al. [78] & $\mathrm{Ag}$ & S. aureus and E. coli & МС3Т3-E1 \\
\hline & Zhang et al. [79] & $\mathrm{Zn}$ and $\mathrm{Ag}$ & S. aureus & - \\
\hline 2017 & Rokosz et al. [80] & $\mathrm{Cu}$ & - & - \\
\hline \multirow[t]{9}{*}{2018} & Zhang et al. [81] & $\mathrm{Cu}$ & S. aureus & $\begin{array}{l}\text { MC3T3-E1 and } \\
\text { Endothelial cells }\end{array}$ \\
\hline & Aydogan et al. [82] & $\mathrm{Ag}$ & S. aureus & Saos-2 \\
\hline & Zhang et al. [83] & $\mathrm{Cu}$ and $\mathrm{Zn}$ & S. aureus & L-929 \\
\hline & Roknian et al. [84] & $\mathrm{Zn}$ & S. aureus and E. coli & - \\
\hline & Sopchenski et al. [85] & $\mathrm{Zn}$ & S. aureus and $P$. aeruginosa & ADSCs \\
\hline & Huang et al. [86] & $\mathrm{Cu}$ & S. aureus & RAW 264.7 and Saos-2 \\
\hline & Sopchenski et al. [87] & B & S. aureus and $P$. aeruginosa & ADSCs \\
\hline & Zhou et al. [88] & $\mathrm{F}$ & S. aureus and E. coli & Rabbit MSC \\
\hline & Du et al. [89] & $\mathrm{Zn}$ & S. aureus and E. coli & - \\
\hline \multirow[t]{8}{*}{2019} & Zhao et al. [90] & $\mathrm{Cu}$ and $\mathrm{F}$ & S. aureus & MC3T3-E1 \\
\hline & Li et al. [91] & $\mathrm{Fe}$ & S. aureus & L929 \\
\hline & Zhang et al. [92] & $\mathrm{Cu}$ & - & - \\
\hline & Zhou et al. [93] & Co and $\mathrm{F}$ & S. aureus and E. coli & MSCs \\
\hline & Zhang et al. [94] & $\mathrm{Zn}$ & E. coli & - \\
\hline & Zhang et al. [95] & $\mathrm{Zn}$ & E. coli & MC3T3-E1 \\
\hline & Shimabukuro et al. [96] & $\mathrm{Ag}$ & S. aureus and E. coli & MC3T3-E1 \\
\hline & Shimabukuro et al. [97] & $\mathrm{Zn}$ & E. coli & MC3T3-E1 \\
\hline \multirow[t]{5}{*}{2020} & Zhang et al. [98] & $\mathrm{Ag}$ & E. coli & - \\
\hline & Zhang et al. [99] & $\mathrm{Cu}$ & S. aureus & MC3T3-E1 \\
\hline & Zhang et al. [100] & $\mathrm{Ag}$ & S. aureus & MC3T3-E1 \\
\hline & Shimabukuro et al. [101] & $\mathrm{Cu}$ & S. aureus and E. coli & MC3T3-E1 \\
\hline & Shimabukuro et al. [102] & $\mathrm{Ag}$ and $\mathrm{Cu}$ & E. coli & - \\
\hline
\end{tabular}

\section{Dual-Functionalization by Mao}

$\mathrm{Ag}, \mathrm{Cu}$, and $\mathrm{Zn}$ in the oxide layer develop both antibacterial properties and cytotoxicity in a dose-dependent manner. Ning et al. [107] reported that suitable concentration ranges of $\mathrm{Ag}$, $\mathrm{Cu}$, and $\mathrm{Zn}$ ions can kill both S. aureus and E. coli without harmful effects on fibroblasts. In the case of implant surfaces, antibacterial properties and absence of harmful effects on osteoblasts play an important role in preventing infection and bone reconstruction. Therefore, it is necessary to realize the importance of both antibacterial properties and biocompatibility on the Ti surface-namely, dual-functionalization by MAO. A conceptual diagram of the dual-functionalization of the Ti surface is shown in Figure 3. The half maximal inhibitory concentrations $\left(\mathrm{IC}_{50} \mathrm{~s}\right)$ of $\mathrm{Ag}, \mathrm{Cu}$, and $\mathrm{Zn}$ ions against MC3T3-E1 cells were 2.77, 15.9, $90.0 \mu \mathrm{M}$, respectively [53]. Therefore, Ag should be the most toxic element in osteoblasts. However, previous studies have revealed that a slight amount of $\mathrm{Ag}$ did not affect the osteoblast activity $[68,78,82,96,100]$. Moreover, the specimen with suitable amounts of Ag had no influence on differentiation and accelerated the calcification [96]. Therefore, the incorporation of a suitable amount of Ag by MAO achieved a dual function on the Ti surface. The biocompatibility of Cu-incorporated specimens was evaluated using a wide variety of cells. The large amount of $\mathrm{Cu}$ developed cytotoxicity in osteoblast [81] and fibroblast cells [77], and the specimen with a suitable amount of $\mathrm{Cu}$ exhibited a good interaction with hard and soft tissues. A slight amount of $\mathrm{Cu}$ on the Ti surface promoted the responses of osteoblasts, fibroblasts, and endothelial cells $[70,77,81,86,90,99,101]$. Huang et al. reported 
that the Cu-incorporated surface contributed to the improvement of both the macrophage-mediated bone formation and bactericidal capacity [86]. In addition to the incorporation of other elements, large amount sof $\mathrm{Zn}$ on the Ti surface exhibited cytotoxicity against osteoblasts, and a suitable amount of $\mathrm{Zn}$ promoted its response $[71,85,95,97]$. Hence, the quantitative control of the incorporation of $\mathrm{Ag}, \mathrm{Cu}$, and $\mathrm{Zn}$ plays a key role in the dual-functionalization of the Ti surface by MAO. In addition, some researchers have reported that the surface structure is one of the key factors in the osteoinductive ability [108]. Therefore, the typical porous structure formed by MAO may be influenced for the improvement of the osteoinduction of implants.

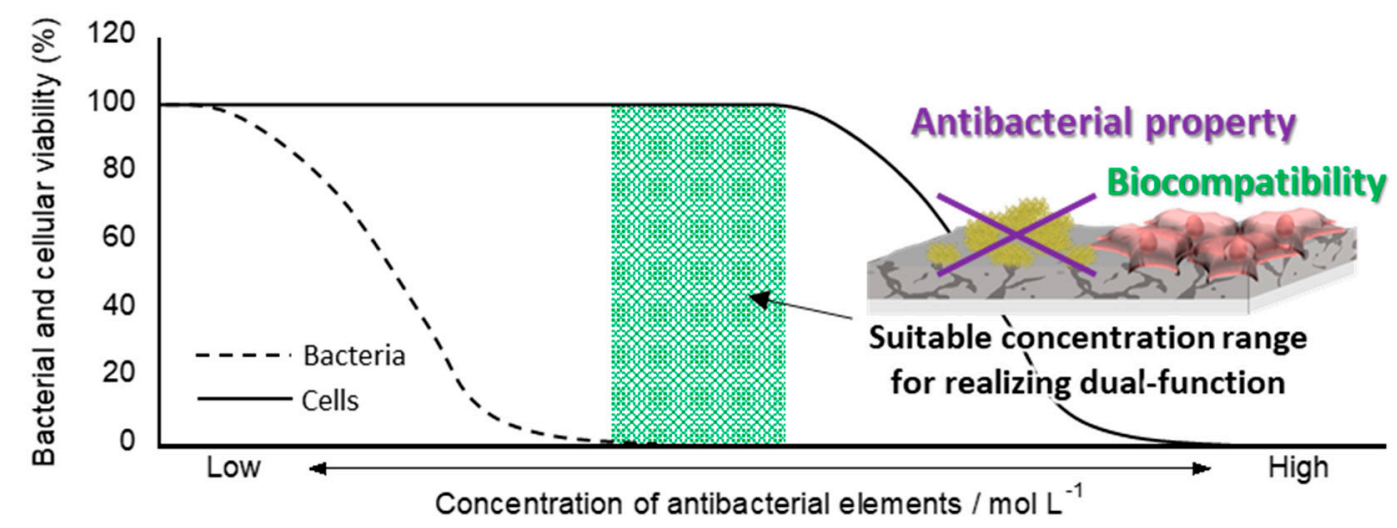

Figure 3. Conceptual diagram of the suitable concentration range (green-colored area) of antibacterial elements for the dual-functionalization of the Ti surface.

\section{Time-Transient Effects of $\mathrm{Ag}, \mathrm{Cu}$, and $\mathrm{Zn}$ on Their Antibacterial Properties}

Prosthetic joint infections are generally categorized into two types: early infections (within 3 months after surgery) and late infections (12 months after surgery). The main cause of late infections is bacterial invasion due to hematogenous spread from another site [109]. On the other hand, Coventry et al. sorted late infection into three types: early postoperative infection (infection occurring within less than 1 month after insertion), late acute infection (infection occurring more than 1 month after insertion, with symptom duration less than 7 days), or late insidious infection (infection occurring more than 1 month after insertion, with symptom duration more than 7 days) [110]. Therefore, the antibacterial surface should be designed to prevent long-term infections. In particular, the long-term inhibition of biofilm formation relies on the durability of antibacterial effects. Surface changes are key in the development of antibacterial effects. Therefore, the biodegradation behavior must be precisely characterized to understand its antibacterial effect and durability. Our previous studies $[97,102]$ simulated the biodegradation behaviors of $\mathrm{Ag}-, \mathrm{Cu}-$, and $\mathrm{Zn}$-incorporated Ti surfaces by immersion in physiological saline for 28 days to investigate the changes in surface composition, chemical states, and antibacterial effects. The surface concentrations of $\mathrm{Ag}, \mathrm{Cu}$, and $\mathrm{Zn}$ were dramatically decreased by incubation for up to 7 days and remained at slight amounts until 28 days (Figure 4a). The antibacterial effect of Ag-incorporated specimens was weakened, the effect of $\mathrm{Cu}$ was maintained, and the effect of $\mathrm{Zn}$ was improved after 28 days of incubation in saline (Figure $4 \mathrm{~b}$ ). The antibacterial effects of these elements relied on their changes in chemical states. After incubation in saline, the chemical states of $\mathrm{Ag}, \mathrm{Cu}$, and $\mathrm{Zn}$ in the oxide layers changed as follows: $\mathrm{Ag}_{2} \mathrm{O}$ to $\mathrm{Ag}, \mathrm{Cu}_{2} \mathrm{O}$ (stable), and $\mathrm{Zn}^{2+}$ to $\mathrm{ZnO}$ (Table 3). Hence, the biodegradation behavior of antibacterial surfaces must be considered for both understanding their durability and preventing late infections. 

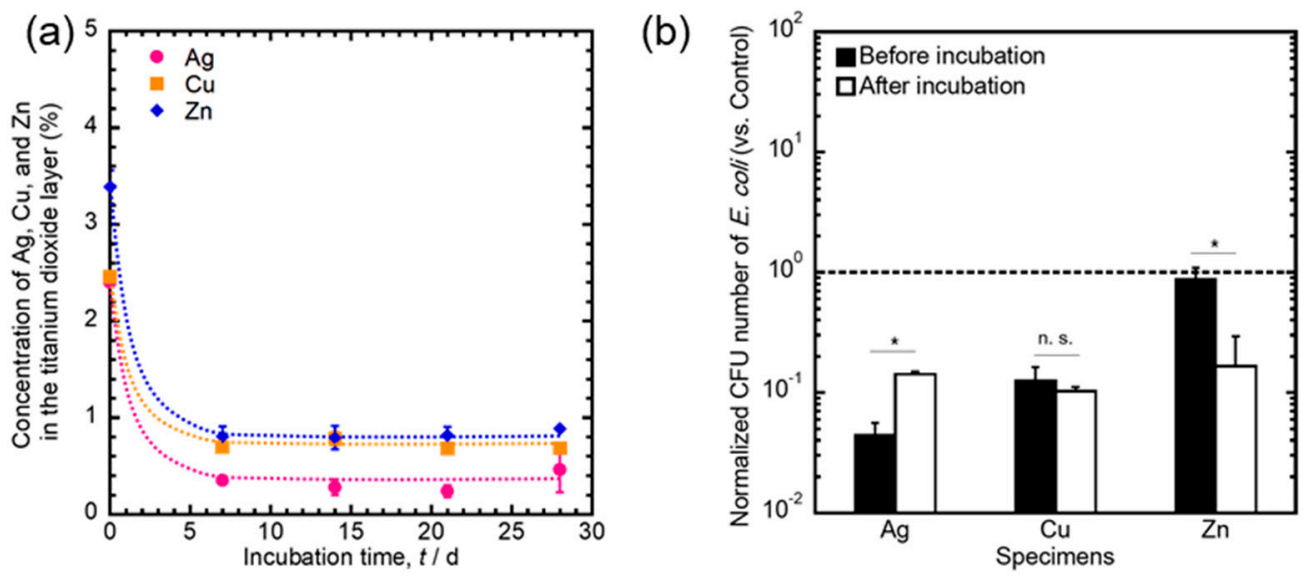

Figure 4. Changes in the concentration of $\mathrm{Ag}, \mathrm{Cu}$, and $\mathrm{Zn}$ in the oxide layer (a) and antibacterial effects (b) before and after incubation in saline for 28 days $[97,102]$.

Table 3. Summary of the binding energy $\left(E_{B}\right)$, kinetic energy $\left(E_{K}\right)$, and modified Auger parameter $\left(\alpha^{\prime}\right)$ values obtained from $\mathrm{Ag}-, \mathrm{Cu}-$, and $\mathrm{Zn}$-incorporated oxide layers before and after incubation in saline for 28 days [97,102].

\begin{tabular}{cccccc}
\hline Elements & Incubation Time/d & $E_{\boldsymbol{B}} / \mathbf{e V}$ & $\boldsymbol{E}_{\boldsymbol{K}} / \mathbf{e V}$ & $\boldsymbol{\alpha}^{\prime} / \mathbf{e V}$ & Chemical State \\
\hline $\mathrm{Ag}$ & 0 & 368.1 & 356.8 & 724.9 & $\mathrm{Ag}_{2} \mathrm{O}$ \\
& 28 & 368.5 & 357.6 & 726.1 & $\mathrm{Ag}$ \\
$\mathrm{Cu}$ & 0 & 933.1 & 916.5 & 1849.6 & $\mathrm{Cu}_{2} \mathrm{O}$ \\
& 28 & 933.3 & 916.2 & 1849.5 & $\mathrm{Cu}_{2} \mathrm{O}$ \\
$\mathrm{Zn}$ & 0 & 1025.8 & 983.6 & 2009.4 & $\mathrm{Zn}^{2+}$ \\
& 28 & 1024.9 & 985.4 & 2010.3 & $\mathrm{ZnO}$ \\
\hline
\end{tabular}

\section{Conclusions}

Biomaterial-associated infections are caused by the formation of biofilms on implant surfaces and are still an important clinical issue. The incorporation of antibacterial elements by MAO is an effective approach for preventing biofilm formation owing to the dual-functionalization of the Ti surface based on the quantitative control of the incorporated elements.

The incorporation of Ag by MAO leads to both the highest antibacterial effect and the highest cytotoxic risk. However, the quantitative control of the incorporation of $\mathrm{Ag}$ leads to the realizing both antibacterial property and biocompatibility. The biodegradation behavior of Ag incubated in saline could affect the durability of the antibacterial effects.

The antibacterial effects and the cytotoxic risks caused by the incorporation of $\mathrm{Cu}$ and $\mathrm{Zn}$ are lower than those of Ag. Moreover, suitable amounts of these elements promote osteoblast responses. The antibacterial effect of $\mathrm{Cu}$ remains for at least 28 days, and that of $\mathrm{Zn}$ was developed after 28 days of incubation in saline. These specific phenomena will help the control of antibacterial effects on the implant surface in the long term.

However, the durability of the antibacterial effect remains unclear and is necessary for preventing late infections. Based on the prosthetic joint infections classification, the antibacterial effect should remain for at least 3 months, and ideally for 1 year. The antibacterial surface on implants should be controlled and designed based on the biodegradation behaviors in the body. Finally, the author hopes that the incorporation of antibacterial elements by MAO can help to eradicate biomaterial-associated infections.

Funding: This research received no external funding.

Acknowledgments: This study was supported, in part, JSPS KAKENHI Grant Number JP20K23032. The authors would like to thank Takao Hanawa (Institute of Biomaterials and Bioengineering, Tokyo Medical and Dental University), and Yusuke Tsutsumi (National Institute for Materials Science) for inspiring the present work. 
Conflicts of Interest: The authors declare no conflict of interest.

\section{References}

1. Hanawa, T. Titanium-tissue interface reaction and its control with surface treatment. Front. Bioeng. Biotechnol. 2019, 17, 170. [CrossRef]

2. Brånemark, P.I.; Hansson, B.O.; Adell, R.; Breine, U.; Lindström, J.; Hallén, O.; Ohman, A. Osseointegrated implants in the treatment of the edentulous jaw. Experience from a 10-year period. Scand. J. Plast. Reconstruct. Surg. Hand Surg. 1977, 11 (Suppl. S16), 1-132.

3. Albrektsson, T.; Hansson, H.A. An ultrastructural characterization of the interface between bone and sputtered titanium or stainless steel surfaces. Biomaterials 1986, 7, 201-205. [CrossRef]

4. Davies, J.E.; Lowenberg, B.; Shiga, A. The bone titanium interface In Vitro. J. Biomed. Mater. Res. 1990, 24, 1289-1306. [CrossRef] [PubMed]

5. Listgarten, M.A.; Buser, D.; Steinemann, S.G.; Donath, K.; Lang, N.P.; Weber, H.P. Light and transmission electron microscopy of the intact interfaces between non-submerged titanium-coated epoxy resin implants and bone or gingiva. J. Dent. Res. 1992, 71, 364-371. [CrossRef] [PubMed]

6. Sennerby, L.; Thomsen, P.; Ericson, L.E. Early tissue response to titanium implants inserted in rabbit cortical bone. J. Mater. Sci. Mater. Med. 1993, 4, 494-502. [CrossRef]

7. Branemark, R.; Ohrnell, L.O.; Skalak, R.; Carlsson, L.; Brånemark, P.I. Biomechanical characterization of osseointegration: An experimental in vivo investigation in the beagle dog. J. Orthop. Res. 1998, 16, 61-69. [CrossRef] [PubMed]

8. Sundell, G.; Dahlin, C.; Andersson, M.; Thuvander, M. The bone-implant interface of dental implants in humans on the atomic scale. Acta Biomater. 2017, 48, 445-450. [CrossRef]

9. Nakayama, Y.; Yamamuro, T.; Kotoura, Y.; Oka, M. In vivo measurement of anodic polarization of orthopaedic implant alloys: Comparative study of in vivo and in vitro experiments. Biomaterials 1989, 10, 420-424. [CrossRef]

10. Brunette, D.M.; Tenvall, P.; Textor, M.; Thomsen, P. (Eds.) Titanium in Medicine; Springer: Berlin, Germany, 2001.

11. Asri, R.I.M.; Harun, W.S.W.; Samykano, M.; Lah, N.A.C.; Ghani, S.A.C.; Tarlochan, F.; Raza, M.R. Corrosion and surface modification on biocompatible metals: A review. Mater. Sci. Eng. C 2017, 77, 1261-1274. [CrossRef]

12. Manam, N.S.; Harum, W.S.W.; Shri, D.N.A.; Ghani, S.A.C.; Kurniawan, T.; Ismail, M.H. Study of corrosion in biocompatible metals for implants: A review. J. Alloys Compd. 2017, 701, 698-715. [CrossRef]

13. Eliaz, N. Corrosion of metallic biomaterials: A review. Materials 2019, 12, 407. [CrossRef] [PubMed]

14. Grainger, D.W.; van der Mei, H.C.; Jutte, P.C.; van den Dungen, J.J.A.M.; Schultz, M.J.; van der Laan, B.F.A.M.; Zaat, S.A.J.; Busscher, H.J. Critical factors in the translation of improved antimicrobial strategies for medical implants and devices. Biomaterials 2013, 34, 9237-9243. [CrossRef] [PubMed]

15. Dibart, S.; Warbington, M.; Su, M.F.; Skobe, Z. In vitro evaluation of the implant-abutment bacterial seal: The locking taper system. Int. J. Oral Maxillofac. Implant. 2005, 20, 732-737.

16. Glauser, R.; Schupbach, P.; Gottlow, J.; Hammerle, C.H. Periimplant soft tissue barrier at experimental one-piece mini-implants with different surface topography in humans: A light-microscopic overview and histometric analysis. Clin. Implant. Dent. Relat. Res. 2005, 7, S44-S51. [CrossRef]

17. Tesmer, M.; Wallet, S.; Koutouzis, T.; Lundgren, T. Bacterial colonization of the dental implant fixture-abutment interface: An in vitro study. J. Periodontol. 2009, 80, 1991-1997. [CrossRef]

18. MacKintosh, E.E.; Patel, J.D.; Marchant, R.E.; Anderson, J.M. Effects of biomaterial surface chemistry on the adhesion and biofilm formation of Staphylococcus epidermidis in vitro. J. Biomed. Mater. Res. A 2006, 78, 836-842. [CrossRef]

19. Busscher, H.J.; van der Mei, H.C.; Subbiahdoss, G.; Jutte, P.C.; van den Dungen, J.J.; Zaat, S.A.; Schultz, M.J.; Grainger, D.W. Biomaterial-associated infection: Locating the finish line in the race for the surface. Sci. Transl. Med. 2012, 26, 153. [CrossRef]

20. Bozic, K.J.; Ries, M.D. The impact of infection after total hip arthroplasty on hospital and surgeon resource utilization. J. Bone Jt. Surg. Am. 2005, 87, 1746-1751. 
21. Lavernia, C.; Lee, D.J.; Hernandez, V.H. The increasing financial burden of knee revision surgery in the United States. Clin. Orthop. Relat. Res. 2006, 446, 221-226. [CrossRef]

22. Costerton, J.W.; Cheng, K.J.; Geesey, G.G.; Ladd, T.I.; Nickel, J.C.; Dasgupta, M.; Marrie, T.J. Bacterial biofilms in nature and disease. Annu. Rev. Microbiol. 1987, 41, 435-464. [CrossRef] [PubMed]

23. Lindsay, D.; von Holy, A. Bacterial biofilms within the clinical setting: What healthcare professionals should know. J. Hosp. Infect. 2006, 64, 313-325. [CrossRef] [PubMed]

24. Fux, C.A.; Costerton, J.W.; Stewart, P.S.; Stoodley, P. Survival strategies of infectious biofilms. Trends Microbiol. 2005, 13, 34-40. [CrossRef] [PubMed]

25. Stewart, P.S.; Costerton, J.W. Antibiotic resistance of bacteria in biofilms. Lancet 2001, 358, 135-138. [CrossRef]

26. Hoiby, N.; Bjarnsholt, T.; Givskov, M.; Molin, S.; Ciofu, O. Antibiotic resistance of bacterial biofilms. Int. J. Antimicrob. Agents 2010, 34, 322-332. [CrossRef]

27. Koo, H.; Allan, R.N.; Howlin, R.P.; Stoodley, P.; Hall-Stoodley, L. Targeting microbial biofilms: Current and prospective therapeutic strategies. Nat. Rev. Microbiol. 2017, 15, 740-755. [CrossRef]

28. Cozens, D.; Read, R.C. Anti-adhesion methods as novel therapeutics for bacterial infections. Expert Rev. Anti. Infect. Ther. 2012, 10, 1457-1468. [CrossRef]

29. Chapman, M.R.; Robinson, L.S.; Pinkner, J.S.; Roth, R.; Heuser, J.; Hammar, M.; Normark, S.; Hultgren, S.J. Role of Escherichia coli curli operons in directing amyloid fiber formation. Science 2002, 295, 851-855. [CrossRef]

30. Serra, D.O.; Richter, A.M.; Klauck, G.; Mika, F.; Hengge, R. Microanatomy at cellular resolution and spatial order of physiological differentiation in a bacterial biofilm. mBio 2013, 4, e00103-13. [CrossRef]

31. Flemming, H.C.; Wingender, J.; Szewzyk, U.; Steinberg, P.; Rice, S.A.; Kjelleberg, S. Biofilms: An emergent form of bacterial life. Nat. Rev. Microbiol. 2016, 14, 563-575. [CrossRef]

32. Van Acker, H.; Van Dijck, P.; Coenye, T. Molecular mechanisms of antimicrobial tolerance and resistance in bacterial and fungal biofilms. Trends Microbiol. 2014, 22, 326-333. [CrossRef] [PubMed]

33. Lebeaux, D.; Ghigo, J.M.; Beloin, C. Biofilm-related infections: Bridging the gap between clinical management and fundamental aspects of recalcitrance toward antibiotics. Microbiol. Mol. Biol. Rev. 2014, 78, 510-543. [CrossRef] [PubMed]

34. Miller, M.B.; Bassler, B.L. Quorum sensing in bacteria. Annu. Rev. Microbiol. 2001, 55, 165-199. [CrossRef]

35. Leckband, D.; Sheth, S.; Halperin, A. Grafted poly(ethylene oxide) brushes as nonfouling surface coatings. J. Biomater. Sci. Polym. Ed. 1999, 10, 1125-1147. [CrossRef]

36. Roosjen, A.; Kaper, H.J.; van der Mei, H.C.; Norde, W.; Busscher, H.J. Inhibition of adhesion of yeasts and bacteria by poly(ethylene oxide)-brushes on glass in a parallel plate flow chamber. Microbiology 2003, 149, 3239-3246. [CrossRef] [PubMed]

37. Park, K.D.; Kim, Y.S.; Han, D.K.; Kim, Y.H.; Lee, E.H.; Suh, H.; Choi, K.S. Bacterial adhesion on PEG modified polyurethane surfaces. Biomaterials 1998, 19, 851-859. [CrossRef]

38. Fujii, K.; Matsumoto, H.N.; Koyama, Y.; Iwasaki, Y.; Ishihara, K.; Takakuda, K. Prevention of biofilm formation with a coating of 2-methacryloyloxyethyl phosphorylcholine polymer. J. Vet. Med. Sci. 2008, 70, 167-173. [CrossRef]

39. Campoccia, D.; Montanaro, L.; Arciola, C.R. A review of the biomaterials technologies for infection-resistant surfaces. Biomaterials 2013, 34, 8533-8554. [CrossRef]

40. Tanaka, Y.; Matin, K.; Gyo, M.; Okada, A.; Tsutsumi, Y.; Doi, H.; Nomura, N.; Tagami, J.; Hanawa, T. Effects of electrodeposited poly(ethylene glycol) on biofilm adherence to titanium. J. Biomed. Mater. Res. A 2010, 95A, 1105-1113. [CrossRef]

41. Berger, T.J.; Spadaro, J.A.; Chapin, S.E.; Becker, R.O. Electrically generated silver ions: Quantitative effects on bacterial and mammalian cells. Antimicrob. Agents Chemother. 1976, 9, 357-358. [CrossRef]

42. Kvitek, L.; Panacek, A.; Prucek, R.; Soukupova, J.; Vanickova, M.; Kolar, M.; Zboril, R. Antibacterial activity and toxicity of silver-Nanosilver versus ionic silver. J. Phys. Conf. Ser. 2011, 304, 012029. [CrossRef]

43. Du, W.L.; Xu, Y.L.; Xu, Z.R.; Fan, C.L. Preparation, characterization and antibacterial properties against E coli K88 of chitosan nanoparticles loaded copper ions. Nanotechnology 2008, 19, 085707. [CrossRef] [PubMed]

44. Shimabukuro, M.; Ito, H.; Tsutsumi, Y.; Nozaki, K.; Chen, P.; Yamada, R.; Ashida, M.; Nagai, A.; Hanawa, T. The effects of various metallic surfaces on cellular and bacterial adhesion. Metals 2019, 9, 1145. [CrossRef]

45. Zhang, W.; Li, Y.; Niu, J.; Chen, Y. Photogeneration of reactive oxygen species on uncoated silver, gold, nickel, and silicon nanoparticles and their antibacterial effects. Langmuir 2013, 29, 4647-4651. [CrossRef] [PubMed] 
46. Page, K.; Wilson, M.; Parkin, I.P. Antimicrobial surfaces and their potential in reducing the role of the inanimate environment in the incidence of hospital-acquired infections. J. Mater. Chem. 2009, 19, 3819-3831. [CrossRef]

47. Chaloupka, K.; Malam, Y.; Seifalian, A.M. Nanosilver as a new generation of nanoproduct in biomedical applications. Trends Biotechnol. 2010, 28, 580-588. [CrossRef]

48. Eckhardt, S.; Brunetto, P.S.; Gagnon, J.; Priebe, M.; Giese, B.; Fromm, K.M. Nanobio silver: Its interactions with peptides and bacteria, and its uses in medicine. Chem. Rev. 2013, 113, 4708-4754. [CrossRef]

49. Lemire, J.A.; Harrison, J.J.; Turner, R.J. Antimicrobial activity of metals: Mechanisms, molecular targets and applications. Nat. Rev. Microbiol. 2013, 11,371-384. [CrossRef]

50. Shirai, T.; Shimizu, T.; Ohtani, K.; Zen, Y.; Takaya, M.; Tsuchiya, H. Antibacterial iodine-supported titanium implants. Acta Biomater. 2011, 7, 1928-1933. [CrossRef]

51. Samani, S.; Hossainalipour, S.M.; Tamizifar, M.; Rezair, H.R. In vitro antibacterial evaluation of sol-gel-derived $\mathrm{Zn-}, \mathrm{Ag}$-, and (Zn + Ag)-doped hydroxyapatite coatings against methicillin-resistant Staphylococcus aureus. J. Biomed. Mater. Res. A 2013, 101, 222-230. [CrossRef]

52. Jin, G.; Qin, H.; Caoa, H.; Qiana, S.; Zhaob, Y.; Peng, X.; Zhang, X.; Liu, X.; Chu, P.K. Synergistic effects of dual $\mathrm{Zn} / \mathrm{Ag}$ ion implantation in osteogenic activity and antibacterial ability of titanium. Biomaterials 2014, 35, 7699-7713. [CrossRef] [PubMed]

53. Yamamoto, A.; Honma, R.; Sumita, M. Cytotoxicity evaluation of 43 metal salts using murine fibroblasts and osteoblastic cells. J. Biomed. Mater. Res. 1998, 39, 331-340. [CrossRef]

54. Ha, J.Y.; Tsutsumi, Y.; Doi, H.; Nomura, N.; Kim, K.H.; Hanawa, T. Enhancement of calcium phosphate formation on zirconium by micro-arc oxidation and chemical treatments. Surf. Coat. Technol. 2011, 205, 4948-4955. [CrossRef]

55. Correa, D.R.N.; Rocha, L.A.; Ribeiro, A.R.; Gemini-Piperni, S.; Archanjo, B.S.; Achete, C.A.; Werckmann, J.; Afonso, C.R.M.; Shimabukuro, M.; Doi, H.; et al. Growth mechanisms of Ca-and P-rich MAO films in Ti-15Zr-xMo alloys for osseointegrative implants. Surf. Coat. Technol. 2018, 344, 373-382. [CrossRef]

56. Li, L.H.; Kim, H.W.; Kim, Y.W.; Kim, H.E.; Heo, S.J.; Koak, J.Y. Improved biological performance of Ti implants due to surface modification by micro-arc oxidation. Biomaterials 2004, 25, 2867-2875. [CrossRef] [PubMed]

57. Li, Y.; Lee, I.S.; Cui, F.Z.; Choi, S.H. The biocompatibility of nanostructured calcium phosphate coated on micro-arc oxidized titanium. Biomaterials 2008, 29, 2025-2032. [CrossRef] [PubMed]

58. Suh, J.Y.; Janga, B.C.; Zhu, X.; Ong, J.L.; Kim, K.H. Effect of hydrothermally treated anodic oxide films on osteoblast attachment and proliferation. Biomaterials 2003, 24, 347-355. [CrossRef]

59. Son, W.W.; Zhu, X.; Shin, H.I.; Ong, J.L.; Kim, K.H. In vivo histological response to anodized and anodized/hydrothermally treated titanium implants. J. Biomed. Mater. Res. B Appl. Biomater. 2003, 66, 520-525. [CrossRef]

60. Kim, D.Y.; Kim, M.; Kim, H.E.; Koh, Y.H.; Kim, H.W.; Jang, J.H. Formation of hydroxyapatite within porous $\mathrm{TiO}_{2}$ layer by micro-arc oxidation coupled with electrophoretic deposition. Acta Biomater. 2009, 5, 2196-2205. [CrossRef]

61. Wang, Y.; Yu, H.J.; Chen, C.Z.; Zhao, Z.H. Review of the biocompatibility of micro-arc oxidation coated titanium alloys. Mater. Des. 2015, 85, 640-652. [CrossRef]

62. Wang, L.; Shi, L.; Chen, J.J.; Shi, Z.F.; Ren, L.; Wang, Y.J. Biocompatibility of Si-incorporated $\mathrm{TiO}_{2}$ film prepared by micro-arc oxidation. Mater. Lett. 2014, 116, 35-38. [CrossRef]

63. Zhang, R.F.; Qiao, L.P.; Qu, B.; Zhang, S.F.; Chang, W.H.; Xiang, J.H. Biocompatibility of micro-arc oxidation coatings developed on Ti6Al4V alloy in a solution containing organic phosphate. Mater. Lett. 2015, 153, 77-80. [CrossRef]

64. Chen, H.T.; Chung, C.J.; Yang, T.C.; Chiang, I.P.; Tang, C.H.; Chen, K.C.; He, J.L. Osteoblast growth behavior on micro-arc oxidized $\beta$-titanium alloy. Surf. Coat. Technol. 2010, 205, 1624-1629. [CrossRef]

65. Cimenoglu, H.; Gunyuz, M.; Kose, G.T.; Baydogan, M.; Ugurlu, F.; Sener, C. Micro-arc oxidation of Ti6Al4V and Ti6Al7Nb alloys for biomedical applications. Mater. Charact. 2011, 62, 304-311. [CrossRef]

66. Liu, W.; Cheng, M.; Wahafu, T.; Zhao, Y.; Qin, H.; Wang, J.; Zhang, X.; Wang, L. The in vitro and in vivo performance of a strontium-containing coating on the low-modulus Ti35Nb2Ta3Zr alloy formed by micro-arc oxidation. J. Mater. Sci. Mater. Med. 2015, 26, 203. [CrossRef] 
67. Wang, G.; Zreiqat, H. Functional coatings or films for hard-tissue applications. Materials 2010, 3, $3994-4050$. [CrossRef]

68. Song, W.H.; Ryu, H.S.; Hong, S.H. Antibacterial properties of Ag (or Pt)-containing calcium phosphate coatings formed by micro-arc oxidation. J. Biomed. Mater. Res. A 2008, 88A, 246-254. [CrossRef]

69. Lin, D.J.; Tsai, M.T.; Shieh, T.M.; Huang, H.L.; Hsu, J.T.; Ko, Y.C.; Fuh, L.J. In vitro antibacterial activity and cytocompatibility of bismuth doped micro-arc oxidized titanium. J. Biomater. Appl. 2013, 27, 553-563. [CrossRef]

70. Zhu, W.; Zhang, Z.; Gu, B.; Sun, J.; Zhu, L. Biological Activity and Antibacterial Property of Nano-structured $\mathrm{TiO} 2$ Coating Incorporated with Cu Prepared by Micro-arc Oxidation. J. Mater. Sci. Technol. 2013, 29, $237-244$. [CrossRef]

71. Zhao, B.H.; Zhang, W.; Wang, D.N.; Feng, W.; Liu, Y.; Lin, Z.; Du, K.Q.; Deng, C.F. Effect of Zn content on cytoactivity and bacteriostasis of micro-arc oxidation coatings on pure titanium. Surf. Coat. Technol. 2013, 228, S428-S432. [CrossRef]

72. Zhao, Q.; Cheng, L.; Liu, Z.; Zhao, J. Surface characteristics of Zinc-TiO 2 coatings prepared via micro-arc oxidation. Compos. Interfaces 2014, 21, 585-593. [CrossRef]

73. Yu, L.; Qian, S.; Qiao, Y.; Liu, X. Multifunctional Mn-containing titania coatings with enhanced corrosion resistance, osteogenesis and antibacterial activity. J. Mater. Chem. B 2014, 33, 5397-5408. [CrossRef] [PubMed]

74. Yao, X.; Zhang, X.; Wu, H.; Tian, L.; Ma, Y.; Tang, B. Microstructure and antibacterial properties of Cu-doped $\mathrm{TiO}_{2}$ coating on titanium by micro-arc oxidation. Appl. Surf. Sci. 2014, 292, 944-947. [CrossRef]

75. Teker, D.; Muhaffel, F.; Menekse, M.; Karagular, N.G.; Baydogan, M.; Cimenoglu, H. Characteristics of multi-layer coating formed on commercially pure titanium for biomedical applications. Mater. Sci. Eng. C 2015, 48, 579-585. [CrossRef]

76. Rokosz, K.; Hryniewicz, T.; Dudek, Ł.; Matýsek, D.; Valicek, J.; Harnicarova, M. SEM and EDS analysis of surface layer formed on titanium after plasma electrolytic oxidation in $\mathrm{H}_{3} \mathrm{PO}_{4}$ with the addition of $\mathrm{Cu}\left(\mathrm{NO}_{3}\right)(2)$. J. Nanosci. Nanotechnol. 2016, 16, 7814-7817. [CrossRef]

77. Zhang, L.; Guo, J.; Huang, X.; Zhang, Y.; Han, Y. The dual function of Cu-doped $\mathrm{TiO}_{2}$ coatings on titanium for application in percutaneous implants. J. Mater. Chem. B 2016, 4, 3788-3800. [CrossRef] [PubMed]

78. He, X.J.; Zhang, X.Y.; Bai, L.; Hang, R.Q.; Huang, X.B.; Qin, L.; Yao, X.H.; Tang, B. Antibacterial ability and osteogenic activity of porous $\mathrm{Sr} / \mathrm{Ag}$-containing $\mathrm{TiO}_{2}$ coatings. Biomed. Mater. 2016, 11, 045008. [CrossRef]

79. Zhang, L.; Gao, Q.; Han, Y. Zn and Ag Co-doped Anti-microbial $\mathrm{TiO}_{2}$ coatings on Ti by micro-arc oxidation. J. Mater. Sci. Technol. 2016, 32, 919-924. [CrossRef]

80. Rokosz, K.; Hryniewicz, T.; Matysek, D.; Raaen, S.; Valicek, J.; Dudek, L.; Harnicarova, M. GDOES, XPS, and SEM with EDS analysis of porous coatings obtained on titanium after plasma electrolytic oxidation. Surf. Interface Anal. 2017, 49, 303-3015. [CrossRef]

81. Zhang, X.; Li, J.; Wang, X.; Wang, Y.; Hang, R.; Huang, X.; Tang, B.; Chu, P.K. Effects of copper nanoparticles in porous $\mathrm{TiO}_{2}$ coatings on bacterial resistance and cytocompatibility of osteoblasts and endothelial cells. Mater. Sci. Eng. C Mater. Biol. Appl. 2018, 82, 110-120. [CrossRef]

82. Aydogan, D.K.; Muhaffel, F.; Kilic, M.M.; Acar, O.K.; Cempura, G.; Baydogan, M.; Karaguler, N.G.; Kose, G.T.; Czyrska-Filemonowicz, A.; Cimenoglu, H. Optimisation of micro-arc oxidation electrolyte for fabrication of antibacterial coating on titanium. Mater. Technol. 2018, 33, 119-126. [CrossRef]

83. Zhang, L.; Guo, J.; Yan, T.; Han, Y. Fibroblast responses and antibacterial activity of Cu and Zn co-doped $\mathrm{TiO}_{2}$ for percutaneous implants. Appl. Surf. Sci. 2018, 434, 633-642. [CrossRef]

84. Roknian, M.; Fattah-alhosseini, A.; Gashti, S.O.; Keshavarz, M.K. Study of the effect of ZnO nanoparticles addition to PEO coatings on pure titanium substrate: Microstructural analysis, antibacterial effect and corrosion behavior of coatings in Ringer's physiological solution. J. Alloys Compd. 2018, 740, 330-345. [CrossRef]

85. Sopchenski, L.; Popat, K.; Soares, P. Bactericidal activity and cytotoxicity of a zinc doped PEO titanium coating. Thin Solid Films 2018, 660, 477-483. [CrossRef]

86. Huang, Q.; Li, X.; Elkhooly, T.A.; Liu, X.; Zhang, R.; Wu, H.; Feng, Q.; Liu, Y. The Cu-containing $\mathrm{TiO}_{2}$ coatings with modulatory effects on macrophage polarization and bactericidal capacity prepared by micro-arc oxidation on titanium substrates. Colloids Surf. B Biointerfaces 2018, 170, 242-250. [CrossRef]

87. Sopchenski, L.; Cogo, S.; Dias-Ntipanyj, M.F.; Elifio-Espósito, S.; Popat, K.C.; Soares, P. Bioactive and antibacterial boron doped $\mathrm{TiO}_{2}$ coating obtained by PEO. Appl. Surf. Sci. 2018, 458, 49-58. [CrossRef] 
88. Zhou, J.H.; Li, B.; Han, Y. F-doped $\mathrm{TiO}_{2}$ microporous coating on titanium with enhanced antibacterial and osteogenic activities. Sci. Rep. 2018, 8, 17858. [CrossRef]

89. Du, Q.; Wei, D.Q.; Wang, Y.M.; Cheng, S.; Liu, S.; Zhou, Y.; Jia, D.C. The effect of applied voltages on the structure, apatite-inducing ability and antibacterial ability of micro arc oxidation coating formed on titanium surface. Bioact. Mater. 2018, 3, 426-433. [CrossRef]

90. Zhao, Q.M.; Yi, L.; Hu, A.N.; Jiang, L.B.; Hong, L.; Dong, J. Antibacterial and osteogenic activity of a multifunctional microporous coating codoped with $\mathrm{Mg}$, $\mathrm{Cu}$ and $\mathrm{F}$ on titanium. J. Mater. Chem. B 2019, 7, 2284-2299. [CrossRef]

91. Li, K.; Liu, S.Y.; Xue, Y.; Zhang, L.; Han, Y. A superparamagnetic $\mathrm{Fe}_{3} \mathrm{O}_{4}-\mathrm{TiO}_{2}$ composite coating on titanium by micro-arc oxidation for percutaneous implants. J. Mater. Chem. B 2019, 7, 5265-5276. [CrossRef]

92. Zhang, X.; Yu, Y.; Jiang, D.; Jiao, Y.; Wu, Y.; Peng, Z.; Zhou, J.; Wu, J.; Dong, Z. Synthesis and characterization of a bi-functional hydroxyapatite/Cu-doped TiO2 composite coating. Ceram. Int. 2019, 45, 6693-6701. [CrossRef]

93. Zhou, J.H.; Wang, X.L.; Zhao, L.Z. Antibacterial, angiogenic, and osteogenic activities of Ca, P, Co, F, and Sr compound doped titania coatings with different Sr content. Sci. Rep. 2019, 9, 14203. [CrossRef] [PubMed]

94. Zhang, X.X.; Li, C.J.; Yu, Y.; Lu, X.Q.; Lv, Y.; Jiang, D.; Peng, Z.; Zhou, J.; Zhang, X.; Sun, S.Q.; et al. Characterization and property of bifunctional $\mathrm{Zn}$-incorporated $\mathrm{TiO}_{2}$ micro-arc oxidation coatings: The influence of different Zn sources. Ceram. Int. 2019, 45, 19747-19756. [CrossRef]

95. Zhang, X.X.; Yang, L.; Lu, X.Q.; Lv, Y.; Jiang, D.; Yu, Y.; Peng, Z.; Dong, Z.H. Characterization and property of dual-functional $\mathrm{Zn}$-incorporated $\mathrm{TiO}_{2}$ micro-arc oxidation coatings: The influence of current density. J. Alloys Compd. 2019, 810, 151893. [CrossRef]

96. Shimabukuro, M.; Tsutsumi, Y.; Yamada, R.; Ashida, M.; Chen, P.; Doi, H.; Nozaki, K.; Nagai, A.; Hanawa, T. Investigation of realizing both antibacterial property and osteogenic cell compatibility on titanium surface by simple electrochemical treatment. ACS Biomater. Sci. Eng. 2019, 5, 5623-5630. [CrossRef]

97. Shimabukuro, M.; Tsutsumi, Y.; Nozaki, K.; Chen, P.; Yamada, R.; Ashida, M.; Doi, H.; Nagai, A.; Hanawa, T. Chemical and biological roles of zinc in a porous titanium dioxide layer formed by micro-arc oxidation. Coatings 2019, 9, 705. [CrossRef]

98. Zhang, L.; Li, B.; Zhang, X.L.; Wang, D.H.; Zhou, L.X.; Li, H.P.; Liang, C.Y.; Liu, S.M.; Wang, H.S. Biological and antibacterial properties of $\mathrm{TiO}_{2}$ coatings containing $\mathrm{Ca} / \mathrm{P} / \mathrm{Ag}$ by one-step and two-step methods. Biomed. Microdevices 2020, 22, 24. [CrossRef]

99. Zhang, X.; Peng, Z.; Lu, X.; Lv, Y.; Cai, G.; Yang, L.; Dong, Z. Microstructural evolution and biological performance of $\mathrm{Cu}$-incorporated $\mathrm{TiO}_{2}$ coating fabricated through one-step micro-arc oxidation. Appl. Surf. Sci. 2020, 508, 144766. [CrossRef]

100. Zhang, Y.Y.; Zhu, Y.; Lu, D.Z.; Dong, W.; Bi, W.J.; Feng, X.J.; Wen, L.M.; Sun, H.; Qi, M.C. Evaluation of osteogenic and antibacterial properties of strontium/silver-containing porous $\mathrm{TiO}_{2}$ coatings prepared by micro-arc oxidation. J. Biomed. Mater. Res. B Appl. Biomater. 2020, in press. [CrossRef]

101. Shimabukuro, M.; Tsutsumi, Y.; Nozali, K.; Chen, P.; Yamada, R.; Aahida, M.; Doi, H.; Nagai, A.; Hanawa, T. Investigation of antibacterial effect of copper introduced titanium surface by electrochemical treatment against facultative anaerobic bacteria. Dent. Mater. J. 2020, 39, 639-647. [CrossRef] [PubMed]

102. Shimabukuro, M.; Hiji, A.; Manaka, T.; Nozaki, K.; Chen, P.; Ashida, M.; Tsutsumi, Y.; Nagai, A.; Hanawa, T. Time-transient effects of silver and copper in the porous titanium dioxide layer on antibacterial properties. J. Funct. Biomater. 2020, 11, 44. [CrossRef] [PubMed]

103. Yu, S.; Yu, Z.T.; Zhang, Q.; Liu, C.C.; Han, J.Y.; Niu, J.L. Research progress of Ag-loaded antibacterial coatings on biomedical titanium alloys. Rare Metal Mater. Eng. 2014, 43, 328-333.

104. Wu, Q.; Li, J.; Zhang, W.; Qian, H.; She, W.; Pan, H.; Zhang, X.; Liu, X.; Kiang, X. Antibacterial property, angiogenic and osteogenic activity of $\mathrm{Cu}$-incorporated $\mathrm{TiO}_{2}$ coating. J. Mater. Chem. B 2014, 39, 6738-6748. [CrossRef] [PubMed]

105. Zhang, X.; Wu, H.; Geng, Z.; Huang, X.; Hang, R.; Ma, Y.; Yao, X.; Tang, B. Microstructure and cytotoxicity evaluation of duplex-treated silver-containing antibacterial $\mathrm{TiO}_{2}$ coatings. Mater. Sci. Eng. C 2014, 45, 402-410. [CrossRef]

106. Jia, Z.J.; Xiu, P.; Li, M.; Xu, X.C.; Shi, Y.Y.; Cheng, Y.; Wei, S.C.; Zheng, Y.F.; Xi, T.F.; Cai, H.; et al. Bioinspired anchoring AgNPs onto micro-nanoporous $\mathrm{TiO}_{2}$ orthopedic coatings: Trap-killing of bacteria, surface-regulated osteoblast functions and host responses. Biomaterials 2016, 75, 203-222. [CrossRef] 
107. Ning, C.Y.; Wang, X.L.; Li, L.H.; Zhu, Y.; Li, M.; Yu, P.; Zhou, L.; Zhou, Z.N.; Chen, J.Q.; Tan, G.X.; et al. Concentration ranges of antibacterial cations for showing the highest antibacterial efficacy but the least cytotoxicity against mammalian cells: Implications for a new antibacterial mechanism. Chem. Res. Toxicol. 2015, 28, 1815-1822. [CrossRef]

108. Habibovic, P.; Yuan, H.P.; van der Valk, C.M.; Meijer, G.; van Blitterswijk, C.A.; de Groot, K. 3D microenvironment as essential element for osteoinduction by biomaterials. Biomaterials 2005, 26, 3565-3575. [CrossRef]

109. Kapadia, B.H.; Berg, R.A.; Daley, J.A.; Fritz, J.; Bhave, A.; Mont, M.A. Periprosthetic joint infection. Lancet 2016, 387, 386-394. [CrossRef]

110. Conventry, M.B. Treatment of infections occurring in total hip surgery. Orthop. Clin. N. Am. 1975, 6, 991-1003.

Publisher's Note: MDPI stays neutral with regard to jurisdictional claims in published maps and institutional affiliations.

(C) 2020 by the author. Licensee MDPI, Basel, Switzerland. This article is an open access article distributed under the terms and conditions of the Creative Commons Attribution (CC BY) license (http://creativecommons.org/licenses/by/4.0/). 